\title{
SUPERVISI PENDIDIKAN DALAM MENINGKATAN MUTU PENDIDIKAN DI SEKOLAH
}

\author{
Oleh: ERLIZA KHAIRIYAH
}

\author{
Erlizakhairiyahh1@gmail.com
}

\begin{abstract}
Sudah menjadi rahasia umum bahwa pendidikan di Indonesia tidak semua merata maju dan berkembang baik disemua daerah, khususnya pada daerah terbelakang dan pelosok. Tidak meratanya semиa kapasitas dan kualitas, sarana dan prasana untuk setiap sekolah yang ada di Indonesia. Hal ini menjadi dampak bagi siswa untuk dapat berprestasi dan mengambangkan kemampuannya. Perlunya supervisi pendidikan yang sangat penting untuk dapat meningkatkan kualitas pendidikan khususnya kepada pengajar atau guru agar dapat meningkatan kreatifitas dan prestasi siswa. Pada saat sekarang ini perlunya pengetahuan yang lebih modren khususnya pada teknologi komunikasi, namun tidak hanya itu saja pengembangan pengetahuan di masyarakat, budaya serta ilmu eksak lainnya juga penting bagi kualitas pendidikan yang semakin maju. Dengan menggunakan teknik-teknik supervisi diharapkan pendidikan akan mencapai titik yang lebih baik lagi. Semua hal tersebut dilakukan untuk menempatkan pendidik atau guru yang professional dan pendidikan yang lebih baik.
\end{abstract}

Kata kunci: supervis pendidikan, pendidikan yang berkualitas.

\section{PEMBAHASAN}

\section{Supervisi pendidikan}

Supervisi pendidikan adalah pembinaan yang berupa bimbingan atau tuntunan ke arah perbaikan situasi pendidikan pada umumnya dan peningkatan mutu mengajar dan belajar dan belajar pada khususnya. Secara Etimologi, supervisi diambil dalam perkataan bahasa Inggris "Supervision" artinya pengawasan di bidang pendidikan. Orang yang melakukan supervisi disebut supervisor.

Menurut Good Carter "Supervisi adalah usaha dari petugas-petugas sekolah dalam memimpin guru-guru dan petugas lainnya, dalam memperbaiki pengajaran, termasuk 
menstimulir, menyeleksi pertumbuhan jabatan dan perkembangan guru-guru dan merevisi tujuan-tujuan pendidikan, bahanbahan pengajaran, dan metode mengajar dan evaluasi pengajaran. God Carter melihatnya sebagai usaha memimpin guru-guru dalam jabatan mengajar".

\section{Beberapa objek dari supervisi,} diantaranya:

a. Supervisi Akademik, yaitu mengamati pada akademik siswa dalam melakukan proses pembelajaran.

b. Supervisi Administrasi, yaitu melihat aspek-aspek administrasi agar mendukung kegiatan belajar siswa untuk kelancarannya.

c. Supervisi Lembaga, yaitu melihat aspek-aspek supervisor pada sentral lembaga madrasah, dengan meningkatkan kualitas kinerja dan nama baik madrasah tersebut.

\section{Tujuan Supervisi pendidikan}

Menurut Piet A. Sahertian dalam bukunya menjelaskan bahwa tujuan supervisi ialah memberikan layanan dan bantuan untuk meningkatkan kualitas mengajar guru dikelas yang pada gilirannya untuk meningkatkan kualitas belajar siswa. Dengan demikian dapat dilihat tujuan supervisi ini untuk dapat meningkatkan kualitas guru dan siswa agar lebih baik.

Dapat disimpulkan bahwa tujuan diadakannya supervisi adalah untuk mengembangkan situasi belajar mengajar yang lebih baik dengan cara membantu guru-guru dalam meningkatkan kinerjanya dalam rangka pembentukan pribadi anak secara maksimal.

Pelaksanaan supervisi dalam meningkatkan kualitas pendidikan di sekolah yang dilakukan oleh individu maupun kelompok, diantaranya:
a. Kunjungan kelas

Kunjungan ke kelas dapat dilakukan oleh kepala sekolah maupun supervisor. Hal ini bertujuan untuk melihat bagaimana cara guru mengajar di dalam kelas. Dengan begitu, dapat melihat bagaimana kesulitan dan keluhan apa yang ada pada guru dan siswa pada saat proses pembelajaran.

\section{b. Percakapan pribadi}

Percakapan pribadi ini dilakukan oleh supervior atau kepala sekoah dengan guru yang mengajar. Berbincang bagaimana poses pembelajaran apakah berjalan dengan 
lancar atau malah sebaliknya. Hal ini juga dapat mengatahui fasilitas apa saja yang kurang pada kegiatan belajar mengajar.

c. Penyeleksi Berbagai Sumber Materi Untuk Mengajar

Menyeleksi sumber materi merupakan hal yang harus dilakukan baik dari pihak supervisor maupun guru. Tujuannya Supaya apa yang akan disampaikan didalam kelas sesuai dengan yang ada dalam kurikulum sehingga tidak menyimpang.

\section{d. Mengadakan rapat}

Dengan diadakannya rapat, supervior atau kepala sekolah dapat memberikan informasi mengenai pelaksanaan pembelajaran untuk dapat lebih baik lagi. Rapat berlangsung harus dengan direncakan matang-matang, agar para guru lainnya dapat bertukar informasi untuk mengetahui apa yang diketahui dan tidak diketahui guru lainnya dalam mengajar.

\section{e. Tindak Lanjut Supervisi Akademik}

Hasil supervisi perlu ditindaklanjuti agar memberikan dampak yang nyata untuk meningkatkan profesionalisme guru. Tindak lanjut tersebut berupa penguatan dan penghargaan; teguran yang bersifat mendidik; dan kesempatan untuk mengikuti pelatihan atau penataran lebih lanjut. Pemanfaatan hasil umpan balik supervisi akademik menyangkut dua kegiatan penting,yaitu berkenaan dengan pembinaan dan pemantapan instrumen supervisi.

\section{f. Pertemuan orientasi}

Pertemuan orientasi adalah pertemuan kepala sekolah dengan guru yang bertujuan menghantar guru tersebut memasuki suasana kerja yang baru. Pada pertemuan orientasi, kepala sekolah memberikan penjelasan mengenai hal-hal penting yang perlu dilakukan dalam rangka meningkatkan kualitas profesionalisme guru dalam melaksanakan tugas pengajaran.

\section{KESIMPULAN}

Dapat disimpulkan bahwa supervisi pendidikan ini sangat penting dalam meningkatkan kualitas pendidika yang lebih baik. Dengan melihat bagaimana aspek di masyarakat, kebudayaan dan teknologi yang ada disekitar sekolah ataupun madrasah. Hal ini bertujuan untuk menciptakan kualitas pendidik dan siswa agar mencapai prestasi serta mengembangkan bakat. Pelaksanaan supervisi pendidikan yang dapat dilakukan individu dan kelompok diantaranya, Kunjungan kelas, Percakapan pribadi, Penyeleksi Berbagai Sumber Materi Untuk 
Mengajar, Mengadakan rapat, Tindak Lanjut

Supervisi Akademik, Pertemuan orientasi.

Jika hal-hal tersebut dapat dilakukan dan berjalan dengan baik pasti kualitas pendidik menjadi profesional dan siswanya dapat menjadi berprestasi sesuai apa yang diinginkan untuk lebih baik.

\section{DAFTAR PUSTAKA}

Sabandi,A.(2013).Suvervisi pendidikan Unttuk Pengembangan Frofesionalitas Guru Berkelanjutan.Pedagogi, Jurnal Ilmu Pendidikan, XIII(2), 1-9, Retrived From http://ejournal.unp.ac.id/index.php/pendagogi/article/view/4275.

http://www.sarjanaku.com/2011/05/supervisi-pendidikan.html

http://repository.radenintan.ac.id/75/7/BAB_II.pdf 